\title{
A Study on Weekly Variation of Urban Air Temperature Difference
}

\author{
Zheng, Hai-Yan ${ }^{1)} \cdot$ Jin, Ri ${ }^{1)} \cdot$ Jin, Wen-cheng ${ }^{1)}$ and Lee, Kyoo-seock ${ }^{2)}$ \\ ${ }^{1)}$ Graduate Student, Department of Landscape Architecture, Sungkyunkwan University, Korea, \\ ${ }^{2)}$ Department of Landscape Architecture, Sungkyunkwan University, Korea.
}

\section{도시 기온차이의 주간 변동에 관한 연구}

\author{
정해연 ${ }^{1)} \cdot$ 김 일 $^{1)} \cdot$ 김문성 $^{1)} \cdot$ 이규석 ${ }^{2)}$ \\ 1) 성균관대학교 대학원 조경학과 · ${ }^{2)}$ 성균관대학교 조경학과
}

\begin{abstract}
국문요약
도시화, 산업화로 인해 도시는 그 주변지역보다 기온이 높은 도시열섬 현상이 발생하고 있으며 이는 인간 활동에 의한 인공폐열 배출량의 증가에 기인한다. 이러한 인간 활동에 의한 도시기온의 변화는 도심과 농촌지역의 차이로 인한 공간적 변이와 아울러 주중과 주간에 기온 차이가 발생하는 시간적 변이를 포함하고 있으나 도시열섬현상의 공간적 변이에 의한 연구에 비해 시간적 변이에 의한 연구는 많이 수행되고 있지 않다. 본 연구에서는 서울 도심의 주중과 주말의 기온차이를 다년간 관측을 통하 여 주중과 주말의 주간 변동의 특성을 파악하여 도시 기온의 시간적 변이를 파악하기 위하여 서울시 강남구를 사례로 2007년 10월 31일부터 2010년 12월 11일까지 약 3년간 관측한 자료를 이용하여 분 석한 결과 5 개 관측지점 모두 주중(weekday)이 주말보다 $1.6 \sim 1.7^{\circ} \mathrm{C}$ 기온이 더 높았으며 이는 주중에 도시 내에서 방출하는 인공폐열의 양이 더 많음을 의미하며 고밀도지역은 냉난방수요가 많아 토지이 용에 따라 기온의 차가 크므로 이를 저감시키기 위한 도시 및 조경계획이 필요하다.
\end{abstract}

Key Words : 도시열섬현상, 주중, 주말, 출근시간.

First author : Hai-Yan Zheng, Graduate Student, Department of Landscape Architecture, Sungkyunkwan University, Korea,

Tel : +82-31-290-7857, E-mail : haiyan0206@ hotmail.com

Corresponding author : Kyoo-seock Lee, Department of Landscape Architecture, Sungkyunkwan University, Korea, Tel : +82-31-290-7845, E-mail : leeks@skku.edu

Received : 9 January, 2012. Revised : 8 May, 2012. Accepted : 16 August, 2012. 


\section{INTRODUCTION}

Rapid urbanization and industrialization have changed the urban climate which has caused some unique climate phenomena. As the urbanization proceeds, the land surface of urban area is changed into concrete and asphalt whose albedo are low resulting in the increase of short wave radiation absorption during daytime. This contributes to the air temperature difference between urban area and rural area, which is known as urban heat island (UHI) (Landsberg, 1981; Oke, 1987). Many researchers investigated the characteristics of UHI in different regions and the mitigation effect of urban green space, rivers and lakes (Upmanis et al., 1998; Kwon, 2001; Whitford, 2001; Wong, 2005; Lee et al., 2009; Lee et, al., 2010).

UHI shows periodic fluctuations. One of these is diurnal and seasonal variations. However, the weekly variation of urban air temperature also occurs because of different amount of human activities between weekday and weekend. Weekly variation was investigated by several foreign researchers (Figuerola and Mazzeo, 1998; Gong et al., 2006; Fujibe, 2010) In Korea, Kim and Baik (2005) investigated the spatial and temporal structure of UHI in Seoul for one year. Seoul has a diverse land use and their microclimate is various even in local area. Therefore, the purpose of this study is to investigate the urban microclimatic characteristics by investigating the weekly variation of air temperature between downtown area and nearby suburban foothill slope area at Gangnam-gu in Seoul.

\section{MATERIALS AND METHODS}

\section{Study site}

The study site is Gangnam-gu, Seoul and the geographic location of the study site ranges from $37^{\circ} 28^{\prime} 34.88^{\prime \prime} \mathrm{N}$ to $37^{\circ} 30^{\prime} 17.46^{\prime \prime} \mathrm{N}$ and from $127^{\circ} 01^{\prime} 34.23^{\prime \prime} \mathrm{E}$ to $127^{\circ} 04^{\prime} 53.40^{\prime \prime} \mathrm{E}$. Seoul is located at center of Korean Peninsula and is in the temperate climate zone of middle latitudes where there are four distinctive seasons. It is cold and dry in winter due to continental high pressure and hot and humid in summer due to North Pacific high pressure. It is clear and dry in spring and fall because of a migratory anticyclone (http : //www.kma.go.kr/weather/climate/average_ south.jsp). From 1971 to 2000, the mean air temperature, mean precipitation and mean wind speed was $12.2^{\circ} \mathrm{C}, 1344.3 \mathrm{~mm}, 2.4 \mathrm{~m} / \mathrm{s}$ respectively according to Korea Meteorological Administration (KMA).

The study site consists of various land use, which includes the central business district (CBD), urban stream, suburban mountain forest and agricultural field. Yangjae Stream flows through the central part of study area and it flows from west to east in the study site. The northern part of the study site is a typical CBD area with high density land use at Gangnam-gu and the southern area is residential area, agricultural field and forest with low density land use (Figure 1).

\section{Observation position description}

In order to investigate the weekly variation of the study area, the air temperature was observed at five observation stations in the study site. Seolleung Subway Station (SLS) is located at the CBD area which is dominantly covered with asphalt and concrete. Dongbu Centreville Apart- 


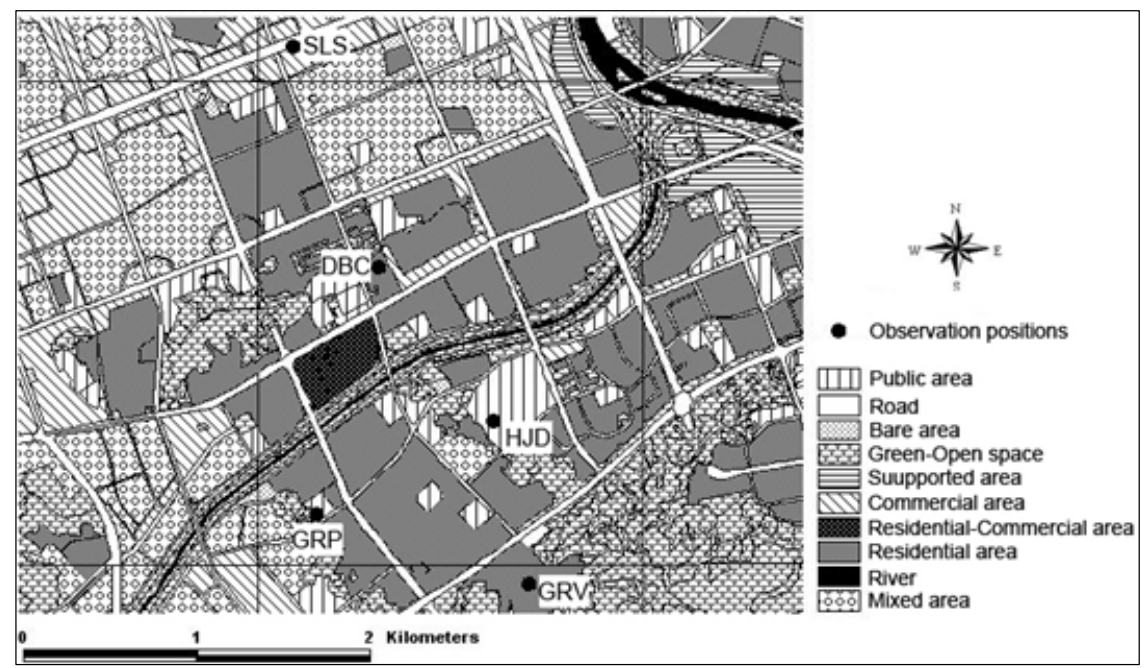

Figure 1. Study site and land use.

ment (DBC) is located at high density residential area and Hanjeon Electrical Co. Dormitory (HJD) is residential facilities covered with grass. Guryong Primary School (GRP) is a four story building. Guryong Village (GRV) is agricultural area located at footslope between Mt. Guryong and Mt. Daemo. The distance between SLS and GRV is $3.5 \mathrm{~km}$ (Figure 2 and Table 1 ).

\section{Observation}

In order to observe the weekly variation of urban air temperature, five Hioki-3641-20 digital temperature-humidity $(\mathrm{TH})$ sensors were installed $2-2.5 \mathrm{~m}$ above the ground to avoid radiation inversion and vandalism. All TH sensors were calibrated before they were installed for data accuracy. The observation interval was 10 minutes

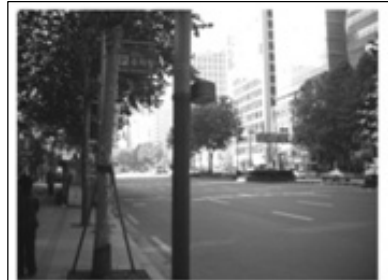

1. SLS

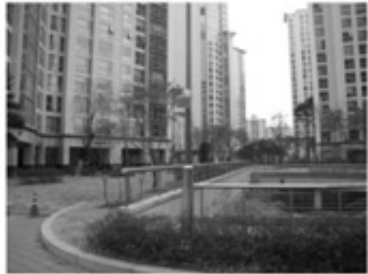

2. DBC

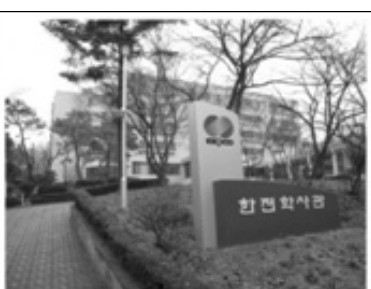

3. HJD

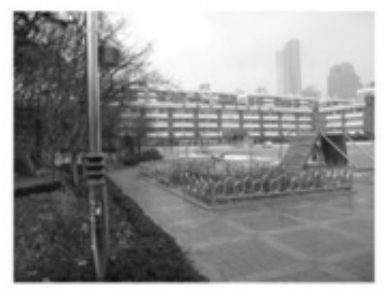

4. GRP

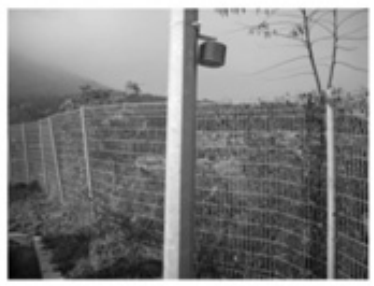

5. GRV

Figure 2. Photos of observation stations. 
Table 1. Description of observation stations.

\begin{tabular}{c|c|c|c|c}
\hline \hline No. & Initial & Observation position & Land use & $\begin{array}{c}\text { Elevation } \\
(\mathrm{m})\end{array}$ \\
\hline 1 & SLS & Seolleung Subway Station & Commercial & 25 \\
\hline 2 & DBC & Dongbu Centreville & Residential & 10 \\
\hline 3 & HJD & Hanjeon Electrical Co. Dormitory & Residential \& Educational & 30 \\
\hline 4 & GRP & Guryong Primary School & Educational & 17 \\
\hline 5 & GRV & Guryong Village & Agricultural & 33 \\
\hline
\end{tabular}

and the observing period was from October 31st, 2007 to December 11th, 2010. Data from Gangnam Automatic Weathering Station (GWS) of KMA were also referred for weather condition during the observation period.

\section{Data analysis}

Weather data which are rainy days, cloud cover with 3 or more and wind speed with $3.4 \mathrm{~m} / \mathrm{s}$ or higher were excluded in analyzing the weekly variation of urban air temperature because significant thermal differences cannot develop in the weather conditions above (Oke, 1987). So, only free convection weather data are used in this study. The number of free convection days used in this study was shown in Table 2 .

Tropical nights for all observing stations were calculated on weekday and weekend during the observing period. A minimum air temperature is equal to $25^{\circ} \mathrm{C}$ or more during the night time (18 : 01 09:00 next morning) is termed a tropical night, according to KMA (http : //web.kma.go.kr/ notify/press/kma_list.jsp?bid=press\&mode=view\& num=1191120). For the weekly variation investigation, Korean national holidays were treated as weekend days (Saturday and Sunday). Weekday is defined from Monday to Friday except national holidays. Then the air temperature difference between weekday and weekend, including the
Table 2. Number of free convection days in each month.

\begin{tabular}{c|c|c}
\hline \hline Month & Selected days & Not selected days \\
\hline January & 47 & 37 \\
\hline February & 35 & 70 \\
\hline March & 26 & 65 \\
\hline April & 26 & 45 \\
\hline May & 18 & 50 \\
\hline June & 15 & 67 \\
\hline July & 2 & 64 \\
\hline August & 14 & 75 \\
\hline September & 24 & 75 \\
\hline October & 26 & 91 \\
\hline November & 39 & 79 \\
\hline December & 39 & 56 \\
\hline Total & $\mathbf{3 1 1}$ & $\mathbf{7 7 4}$
\end{tabular}

difference on rush hour, was analyzed. Air temperature difference between weekday and weekend was analyzed first. Then diurnal and weekly variation of two observation stations where the highest (SLS) and lowest air temperature (GRV) was observed was also analyzed.

\section{RESULTS AND DISCUSSION}

\section{Tropical nights for all observation stations}

For tropical nights on weekday, DBC shows the highest number of 35 days, followed by SLS (34 days), GRP (13 days), HJD (11 days) and 
GRV (3 days). On weekend, DBC and SLS shows 20 days, followed by GRP (4 days), GRV (3 days) and HJD (2 days). For the difference of tropical nights between weekday and weekend, DBC is 15 days, SLS is 14 days, GRP and HJD are 9 days and GRV is 0 (Table 3 and Figure 3). It suggests that tropical night occurrence is related to the land use type in urban area because DBC is located at high density residential area and the tropical night occurred most frequently there. Hage (1972) indicated that the strongest UHI occurred at night in Edmonton, Alberta mainly due to the anthropogenic heat. SLS is located at CBD in Seoul where the tropical night occurred as frequently as DBC because the land surface is covered by concrete and asphalt which absorb solar energy as short wave radiation on daytime and emit as the longwave radiation on nighttime. However, high rise buildings at $\mathrm{CBD}$

Table 3. Numbers of tropical nights on weekday and weekend for the observation stations.

\begin{tabular}{c|c|c|c|c|c}
\hline \hline Day & DBC & SLS & GRP & HJD & GRV \\
\hline weekday & 35 & 34 & 13 & 11 & 3 \\
\hline weekend & 20 & 20 & 4 & 2 & 3 \\
\hline difference & 15 & 14 & 9 & 9 & 0 \\
\hline
\end{tabular}

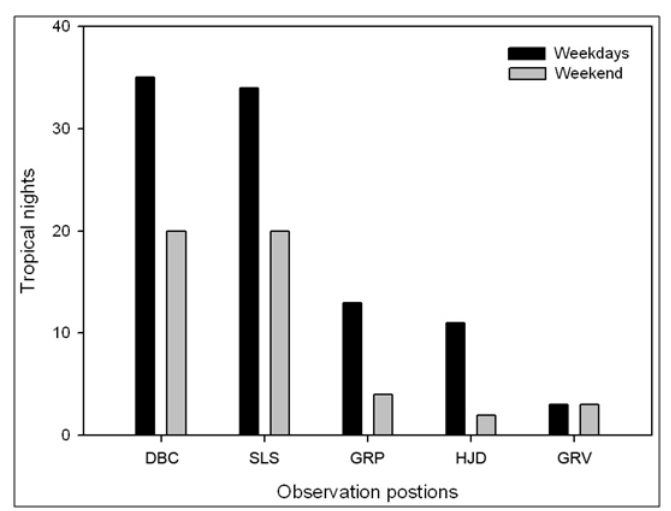

Figure 3. Number of tropical nights on weekday and weekend for the observation stations. cause a low sky view factor and the long wave radiation cannot emit to the sky easily. So the emitted long wave radiation is blocked among buildings and increases the air temperature. While GRV is covered with vegetation and soil with low albedo resulting in more radiation energy exchange compare with DBC or SLS. As a result, the air temperature is lower than other observation stations.

\section{Air temperature variation on weekday and weekend}

The mean annual air temperature on weekday and weekend is shown in Table 4. The highest air temperature on weekday occurred at SLS with $9.2^{\circ} \mathrm{C}$ and followed by DBC $\left(8.7^{\circ} \mathrm{C}\right), \operatorname{GRP}\left(7.8^{\circ} \mathrm{C}\right)$, HJD $\left(7.6^{\circ} \mathrm{C}\right)$ and GRV $\left(7.3^{\circ} \mathrm{C}\right)$, respectively. These mean annual air temperatures are relatively lower than $12.2^{\circ} \mathrm{C}$ by KMA 30 year average temperature. This is due to the low free convection days during summer. Two days and fourteen days are used in July and August, respectively after excluding rainy, cloudy or windy days. On weekend, the highest air temperature also occurred at SLS with $7.5^{\circ} \mathrm{C}$ and the lowest one occurred at GRV with $5.6^{\circ} \mathrm{C}$. The air temperature between SLS and GRV ( $\left.\Delta \mathrm{T}_{\mathrm{SLS}-\mathrm{GRV}}\right)$ is $1.9^{\circ} \mathrm{C}$ both weekday and weekend. The highest air temperature difference between weekday and weekend ( $\Delta$ $\mathrm{T}_{\text {weekday-weekend }}$ ) is $1.7^{\circ} \mathrm{C}$ at SLS and GRV and the difference at other observation stations is $1.6^{\circ} \mathrm{C}$. Fujibe (2010) evaluated air temperature differences among days of the week and their longterm trends from March 1979 to February 2008 in Japan. In his study, weekday-weekend air temperature difference was $0.2 \sim 0.25^{\circ} \mathrm{C}, 0.1 \sim$ $0.2^{\circ} \mathrm{C}$ and $0.02^{\circ} \mathrm{C}$ in Tokyo, Osaka and stations where the population density was 300 to 1000 
Table 4. Mean annual air temperature on weekday and weekend.

(Unit : ${ }^{\circ} \mathrm{C}$ )

\begin{tabular}{c|c|c|c|c|c}
\hline \hline Day & SLS & DBC & GRP & HJD & GRV \\
\hline weekday & 9.2 & 8.7 & 7.8 & 7.6 & 7.3 \\
\hline weekend & 7.5 & 7.1 & 6.2 & 6 & 5.6 \\
\hline$\Delta \mathrm{T}_{\text {weekday-weekend }}$ & 1.7 & 1.6 & 1.6 & 1.6 & 1.7 \\
\hline
\end{tabular}

Table 5. Mean air temperature on rush hour between weekday and weekend.

(Unit : ${ }^{\circ} \mathrm{C}$ )

\begin{tabular}{c|c|c|c|c|c}
\hline \hline Day & SLS & DBC & GRP & HJD & GRV \\
\hline weekday & 6.1 & 5.7 & 4.5 & 4.3 & 4.5 \\
\hline weekend & 4.4 & 4.1 & 2.8 & 2.7 & 2.8 \\
\hline$\Delta \mathrm{T}_{\text {weekday-weekend }}$ & 1.7 & 1.6 & 1.7 & 1.6 & 1.7 \\
\hline
\end{tabular}

person $/ \mathrm{km}^{2}$. The weekday-weekend air temperature differences at three regions with heavy traffic or high commercial activities on weekday were $0.55^{\circ} \mathrm{C}, 0.60^{\circ} \mathrm{C}$ and $0.49^{\circ} \mathrm{C}$ from March 2001 to February 2002 in Seoul (Kim and Baik, 2005). So, the difference of 1.6 to $1.7^{\circ} \mathrm{C}$ at Gangnam is much higher than other parts of Seoul or Japanese cities.

On weekday the anthropogenic heat emission is more than weekend because automobile gas emission is more, especially during rush hour at weekday and people move more frequently for business in urban area while people and automobile movement is less on weekend which causes less anthropogenic heat emission. As a result, air temperature on weekday is higher than that on weekend.

Air temperature during rush hour $(6: 00 \sim 9: 00$ local standard time (LST)) on weekday and weekend for all observation stations were also compared. Air temperature on weekday is always higher than that on weekend. On weekday, air temperature at SLS is the highest by $6.1^{\circ} \mathrm{C}$ while air temperature at HJD is the lowest by $4.5^{\circ} \mathrm{C}$. On weekend, air temperature is also the highest at SLS by $4.4^{\circ} \mathrm{C}$ while it is the lowest at HJD by
2.7 ${ }^{\circ}$, too. $\Delta \mathrm{T}_{\text {weekday-weekend }}$ is $1.7^{\circ} \mathrm{C}$ at SLS, GRP and GRV, $1.6^{\circ} \mathrm{C}$ at DBC and HJD (Table 5).

\section{Diurnal variation of air temperature at SLS and GRV}

In this study, the highest air temperature difference was observed between SLS and GRV. So, the two observation stations were compared to analyze diurnal variation of air temperature. Figure 4 shows the diurnal variation of air temperature on weekday and weekend at SLS and GRV. The highest air temperature difference almost occurred at $6: 00 \sim 7: 00$ LST while the lowest one occurred at $15: 00 \sim 16: 00$ LST as we can see in Figure 4. Air temperature on nighttime at GRV

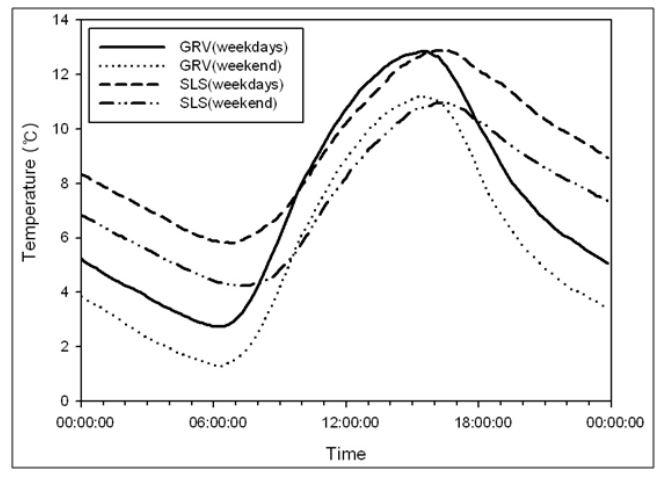

Figure 4. The diurnal air temperature at SLS and GRV on weekday and weekend. 
Table 6. Weekly air temperature at SLS and GRV.

(Unit : ${ }^{\circ} \mathrm{C}$ )

\begin{tabular}{c|c|c|c|c|c|c|c}
\hline \hline & Mon. & Tue. & Wed. & Thu. & Fri. & Sat. & Sun. \\
\hline SLS & 7.8 & 8.5 & 9.5 & 11.7 & 8.1 & 7.5 & 7.5 \\
\hline GRV & 5.8 & 6.8 & 7.5 & 9.6 & 6.2 & 5.5 & 5.7 \\
\hline$\Delta \mathrm{T}_{\text {SLS-GRV }}$ & 2.0 & 1.7 & 2.0 & 2.1 & 1.9 & 2.0 & 1.8 \\
\hline
\end{tabular}

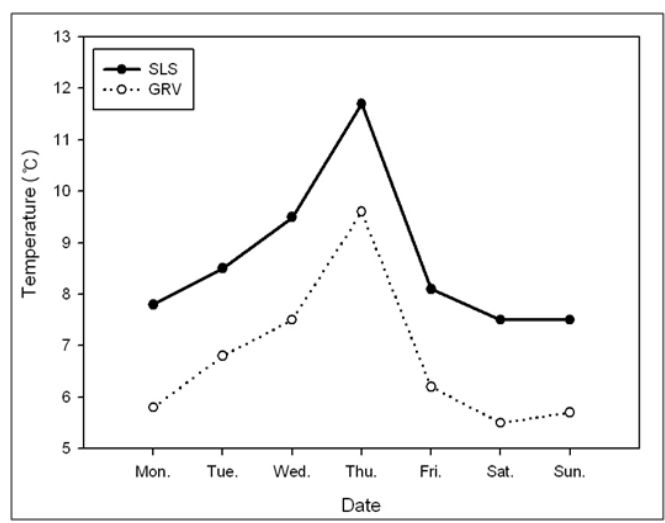

Figure 5. Weekly air temperature at SLS and GRV.

is much lower than SLS both on weekday and weekend because GRV, agricultural area, has more active radiation energy exchange by long wave radiation emission to the sky directly while SLS is located at CBD with low SVF which induces the low emission of long wave radiation and anthropogenic heat trapping among high rise buildings.

\section{Weekly air temperature variation at SLS and GRV}

Air temperature on weekday is higher than weekend both at SLS and GRV. On weekday it is the highest on Thursday by $11.7^{\circ} \mathrm{C}$ at SLS and $9.6^{\circ} \mathrm{C}$ at GRV, followed by Wednesday, Tuesday, Friday and lowest on Monday. $\Delta \mathrm{T}_{\mathrm{SLS}-\mathrm{GRV}}$ is 1 . $7^{\circ} \mathrm{C} \sim 2.1^{\circ} \mathrm{C}$ because of different land use (Table 6 and Figure 5). From Monday to Friday, traffic or commercial activities are higher than that on Saturday and Sunday, which is the main reason of higher temperature on weekday.

\section{CONCLUSION}

In order to investigate the weekly variation of urban air temperature difference, air temperature was observed at five observation stations with different land use type from October 31st, 2007 to December 11th, 2010 at Gangnam-gu, Seoul. After carrying out this study, the following conclusions were derived.

1. The highest number of tropical night and the highest air temperature occurred at high density residential area (DBC and SLS) both on weekday and weekend. Weekday urban air temperature is higher than that on weekend by $1.6^{\circ} \mathrm{C} \sim 1.7^{\circ} \mathrm{C}$ at the study site.

2. During weekday the highest air temperature was observed on Thursday which shows the variation among weekday. However, there is little difference between Saturday and Sunday.

This study shows the cooling degree days (CDD) is higher at high density land use area than rural or suburban mountain area even in local scale within a city. It depends on the land use and topographic characteristics as we can see in suburban mountain. It is due to the different topoclimate which induces the dissimilarity of radiative fluxes and turbulent exchanges. Thus, the urban planning and landscape planning/design should consider these characteristics. In the future, climate sensitive planning/design needs to 
be implemented in Seoul.

\section{ACKNOWLEDGEMENTS}

This research was funded by the Center for Atmospheric and Earthquake Research (CATER 2006-3302).

\section{REFERENCE}

Arya, S. P. 1988. Introduction to micrometeorology. New York: Academic Press, Inc. p.238.

Figuerola, P. I. and N. A. Mazzeo, 1998. Urbanrural temperature differences in Buenos Aires. International Journal of Climatology 18 : 1709-1723.

Fujibe, F. 2010. Day-of-the-week variations of urban temperature and their long-term trends in Japan, Theoretical and Applied Climatology 102(3-4) : 393-401.

Gong, D. D. Guo and C. Ho, 2006. Weekend effect in diurnal temperature range in China : Opposite signals between winter and summer. Journal of Geophysical Research 111 : D18113.

Hage, K. 1972. Nocturnal temperatures in Edmonton, Alberta. Journal of Applied Meteorology and Climatology $11: 123-129$

Kim, Y., and J. Baik, 2005. Spatial and temporal structure of the urban heat island in Seoul, Journal of Applied Meteorology 44 : 591605.

Kwon, Y., and H. Lee, 2001. Spatial distribution of temperature in and around urban parks -A case study of around Changkyeong Palace, Changdeok Palace and Jongmyo in Seoul(written in Korean). Journal of Korean Geo- graphy Society 23(2) : 126-140.

Landsberg, H. E. 1981. The Urban Climate, New York : Academic Press.

Lee, K., D. Shin, J. Kim, S. Lee, H. Lee, W. Jin, and H. Zheng, 2010. Air temperature decreasing effects by restored urban stream. Journal of Environmental Impact Assessment 19(1): 75-81.

Lee S., K. Lee, W. Jin and H. Song. 2009. Effect of an urban park on air temperature differences in a central business district area. Landscape and Ecological Engineering 5(2) : 183-191.

Oke, T. R. 1987. Boundary Layer Climates, 2nd ed. Routledge.

Upmanis, H, I. Eliasson and S. Lindqvist, 1998. The influence of green areas on nocturnal temperatures in a high latitude city (Göteborg, Sweden). International Journal of Climatology $18: 671-700$.

Upmanis, H. and D. Chen, 1999. Influence of geographical factors and meteorological variables on nocturnal urban-park temperature differences-a case study of summer 1995 in Göteborg, Sweden. Climate Research 13 : 125-139.

Wong N., Y. Chen, 2005. Study of green areas and urban heat island in a tropical city. Habitat International $29: 547-558$.

Whitford V., A. R. Ennos and J. F. Handley, 2001. "City form and natural process"indicators for the ecological performance of urban areas and their application to Merseyside, UK. Landscape and Urban Planning 57(2) : 91-103.

Zheng, H., W. Jin and K. Lee, 2009, A study on air temperature-reducing effects by historical landscape-Based on Gwangpyeong Prince 
Tomb-(written in Korean). Journal of Korean Institute of Traditional Landscape Architecture 27(3) : 87-92.

Zheng, H., W. Jin, K. Lee and S. Oh, 2010. A study on air temperature-reducing effects by irrigation reservoir (written in Korean).
Journal of Korea Society of Environmental Restoration Technology 13(1) : 32-39.

http : //www.kma.go.kr/weather/climate/average_ south.jsp

http : //web.kma.go.kr/notify/press/kma_list.jsp?bid $=$ press\&mode $=$ view $\&$ num $=1191120$ 